\title{
Portfolioperikelen: de persoonlijke kant van de specialist in opleiding
}

In onderstaande reactie op de artikelen pro en contra portfolio van M. Vermeulen ${ }^{1}$ en van H.E. Sluiter, F.Y. L. de Vos en E.M. Wever-Kroes, ${ }^{2}$ beschouw ik de artikelen als werkstukken in een portfolio dat ik als hun coach moet beoordelen.

Arts in opleiding tot assistent (aios) Vermeulen heeft de tweede versie van zijn portfolio ingeleverd met daarin een opdracht over portfolio. Op tijd, dat wel. Maar vergeleken met de vorige versie zie ik nauwelijks ontwikkeling. Dat kan morgen nog een lastig tweede gesprek worden. Het eerste gesprek verliep niet echt soepel. Vermeulen kwam binnen en zei meteen: "Het portfolio in de specialistenopleiding dient onmiddellijk te worden afgeschaft." Ik vroeg of hij koffie wilde. Al spoedig bleek dat hij op de basis- en middelbare school en de universiteit langdurig had blootgestaan aan 'projectmatig werken'. Eerste generatie slachtoffers van het 'nieuwe leren' bereikt de specialistenopleiding, schoot door mijn hoofd. Maar ja, dat kun je natuurlijk niet rechtstreeks zeggen. "Tegen een eenvoudig portfolio kan geen bezwaar bestaan", zei hij ruimhartig, "bijvoorbeeld een opsomming van de stages die gevolgd zijn in kliniek of polikliniek. Maar om je vorderingen op te schrijven en daarover te reflecteren, mijn hemel, dan kan een enorme papierwinkel ontstaan, en de vraag is of de opleiding hierdoor verbetert." Vermeulen heeft beslist retorisch talent en ik overwoog even dat op mijn lijstje positieve feedback te zetten. Maar omdat hij de indruk wekte daar zelf ook erg van overtuigd te zijn, zag ik er voorlopig van af.

Ik vroeg hem of hij op neurologie vorderingen had gemaakt. "Absoluut!", zei hij. "Het is een interessant vak met slimme dokters die ingewikkelde puzzels oplossen, dat vind ik leuk. Bovendien een specialisme dat is gebaseerd op 'de objectieve werkelijkheid'." Hij nam een slok van z'n koffie en leunde achterover. Als coach begrijp ik dat wel. Zo'n jongen snakt naar structuur en objectieve kennis, na die tropenjaren waarin 'leerlingen kennis construeren door het geven van betekenis aan ervaringen met de wereld om hen heen'. Gestructureerde kennisoverdracht in een 'hard vak' kan voor deze generatie een enorme empirische steun zijn in de persoonlijke en professionele identiteitsontwikkeling. Als coach moet je daar voorzichtig mee omgaan. Toch had ik met hem afgesproken dat hij zou opschrijven wat hij had geleerd en waar hij nu stond. Dit was duidelijk te hoog gegrepen, hij zit nog helemaal in de post-constructivistische weerstand. "Van de aios wordt verwacht dat hij inzicht krijgt in zijn kennen en kunnen, meestal 'competenties' genoemd", had hij netjes opgeschreven, dat wel. Maar hoe krijg je het als coach voor elkaar - wat toch de ambitie van portfolio-onderwijs is - dat een beginnend specialist een begin van inzicht krijgt in de relatie tussen zijn beroepsmatige en persoonlijke ontwikkeling. Morgen is een kritisch moment. Laat ik eens proberen hem uit te dagen op z'n competentie 'wetenschappelijk denken' en vooral z'n puzzelego - uiteraard nadat ik met positieve feedback ben begonnen volgens de Pendleton-regels. ${ }^{3}$

De volgende ochtend viel ik meteen met de deur in huis. "Je hebt beslist een vlotte pen en een goede performance, je bent ambitieus en toont grote inzet. Prima". Vermeulen keek zo neutraal mogelijk en zei: "Ja, zo beginnen ze allemaal, zegt u het maar." Ik schoot in de lach. "Je bent inderdaad een ervaringsdeskundige. Wat me verontrust is dat je nu al de slechte gewoonte ontwikkelt om je vaste persoonlijke overtuigingen over medisch onderwijs met veel aplomb in een pseudowetenschappelijk jasje te verpakken. Dat is nou precies wat Ron Harden het PHOG-syndroom noemt: het optrekken van een mist bestaande uit 'prejudice, hunch, opinion, 
and guesswork which cloud and obscure the debate'."4 Hij bleef me aankijken alsof hij een totaal nieuwe puzzel voor zich zag. Ik dacht ondertussen: persoonlijke weerstand is een gunstige conditie voor PHOG-vorming, wat het des te moeilijker maakt om er inzicht in te krijgen, laat staan er iets aan te veranderen. Dat is ook de reden waarom het geven van een onvoldoende in dit soort gevallen weinig zin heeft. Een goed gesprek is beter zeg dat wel. Ik keek hem nog eens aan en zag hem in gedachten met z'n patiënten op de afdeling. We spraken enige tijd en Vermeulen bleef er al die tijd met z'n aandacht bij. Ik vatte hoop en greep mijn kans. "Je krijgt een herkansing. Probeer deze keer geen conclusies te trekken die gebaseerd zijn op 'literatuur in tijdschriften die ik nog nooit had gezien (stel je voor!) en die bestond uit slecht geschreven stukken over slecht opgezette onderzoeken, die geen conclusie toelieten', afgaande op argwanende of niet-begrijpende collega's. Man, dat is toch onder jouw niveau! Ik weet dat je een goede bridger bent. Dan weet je dat je door 'het sterk' van je tegenstander moet gaan. Baseer je kritiek op de sterkste argumenten en artikelen van je tegenstanders. Maak onderscheid tussen 'het nieuwe leren' op de basisschool, de middelbare school en in de specialistenopleiding. Ga eens na of er voor 'het oude leren' in de meester-gezel verhouding wel empirische steun te vinden is. Neurologisch onderzoek baseer je toch ook niet op gemakkelijke vooronderstellingen en subjectieve meningen van anderen." Ik pauzeerde even. Hij klapte z'n portfoliomap dicht alsof er ergens een kwartje was gevallen. "Oké", zei hij en stond op, "ik doe m'n best maar het is momenteel erg druk." We gaven elkaar een hand. Ik ben benieuwd of dit gaat werken.

Zo, en nu de volgende opdracht, groepswerk van Sluiter, de Vos en Wever-Kroes. Alweer over portfolio: 'Het portfolio zal de kwaliteit van de specialistenopleiding vergroten'. Hm, eens kijken. "Met het portfolio kan de aios de verdere opleiding plannen in een communicatieve zelfsturing.". Wat is dat nou weer! Dit lijkt een zuiver geval van opkomende 'portfoliose'. ${ }^{5}$ Waarschijnlijk hebben ze elkaar in hun enthousiasme aangestoken, dat heb je met groepswerk. Gelukkig krijgt Vermeulen dit stuk niet onder ogen. Dan schiet hij helemaal in de weerstand en zou mijn uitdagingstactiek alleen maar nuttig voor mezelf zijn. Tja, van een portfolio leert de coach vaak het meest.

Groningen, mei 2007

\section{Leo Aukes}

Tijdens mijn opleiding was een gesprek als hierboven beschreven gelukkig ondenkbaar en ik wens de huidige assistenten hetzelfde toe.

Amsterdam, mei 2007

\section{Vermeulen}

\section{Literatuur}

Vermeulen M. Het portfolio levert geen wezenlijke bijdrage aan de kwaliteit van de specialistenopleiding. Tijdschrift voor Medisch Onderwijs 2007;26:32-3.

Sluiter HE, Vos FYL de, Wever-Kroes EM. Het portfolio zal de kwaliteit van de specialistenopleiding vergroten. Tijdschrift voor Medisch Onderwijs 2007;26:30-1.

Pendleton D, Scofield T, Tate P, Havelock P. The consultation: an approach to learning and teaching. Oxford: Oxford University Press; 1984.

Spencer J. Blowing away the PHOG. Clin Teach 2007;4:1.

Cohen-Schotanus J. Uitbraak van portfoliose? Tijdschrift voor Medisch Onderwijs 2005;24:243-4.
150 